\author{
ANNA SARBIEWSKA* \\ Szczytno, Poland \\ ORCID ID: https://orcid.org/oooo-ooo2-9429-8228
}

\title{
EDUCATION AND ITS VISIBILITY: SCHOOL TRANSFORMATION INITIATIVES IN POLAND
}

\begin{abstract}
This article analyses three present-day educational initiatives undertaken in Polish public schools on the basis of theoretical models of pedagogical culture. Considerations are directed towards actions of teaching, learning and a relationship between them expressed in the term of education. The text consists of four sections. The first section presents pedagogical culture developing three theoretical models of educational concept. The second section provides explanation of the term "visibility" in educational processes with reference to the evidence based research. The third part offers an insight into the foundations of current pedagogical initiatives: Dalton Plan, Non Violent Communication and School Awakening in relation to the idea of visibility. Finally, the last section reviews visibility in educational processes and describes its nature in discussed school reform projects.
\end{abstract}

Keywords: visiblity; learning; teaching; education; Non Violent Communication; School Awakening; Dalton Plan.

\section{Introduction}

Some school teachers notice that current school work where knowledge, skills and moral indications are transferred between the person who has them (a teacher) and the person who should master them (a student) is ineffective and inefficient. This may suggest that predominant presence of teacher in different stages of educational process and facade student's contribution are to be blamed. Therefore, school

\footnotetext{
* Anna Sarbiewska, MA, Szczytno, Poland; e-mail: anna-sarbiewska@wp.pl.
} 
practitioners get involved in pedagogical culture of looking for different, better educational models which focus on modified schooling initiatives, successful projects and innovative solutions.

In this article I will introduce current educational initiatives undertaken by Polish public school teachers with regard to pedagogical research results of Visible Learning theory of John Hattie (2008). My goal is to show the readers the possibilities of changing the existing educational model without the need of introducing system changes. In the first section I will outline theoretical model of effective, innovative model of education with "visible teaching" and "visible learning" contribution. The following section provides an insight into initiatives undertaken by Polish schools analysed in terms of visibility of teaching and learning. The third part of the article sheds light on directions of the undertaken changes, strengths and weaknesses of analysed educational initiatives with emphasis on factual teacher's and student's role. Conclusions illustrate the relevance of pedagogical culture in education improvement and a difference in visibility of educational processes based on pedagogical theory and empirical research data.

\section{Pedagogical culture of education - exploration of educational concepts}

This part prepares the theoretical framework for further considerations. Therefore, I will start with presenting three models of pedagogical culture - closely related to teaching and learning, and the relationship between them - expressed in the term of education ${ }^{1}$.

A traditional Prussian schooling model locates a teacher in a privileged position in relation to a passive, not engaged student. Teacher is an active actor of the educational process and student's role is to listen, take notes and follow instructions directed to him. This concept presumes that teaching equals learning. It is assumed that when a teacher is teaching, a student is learning. In this model, education is understood both as conditions of the undergoing process - school, and a product knowledge transferred from a teacher to a student. There is no need to talk about mutual interaction, because the learner has to blindly follow the teacher. The knowledge he gets at school is rather constructed "in the footsteps" (Klus-Stańska,

1 The close relationship between the above mentioned terms is indicated by David Carr (2003, p. 4) who wrote: "[...] there are apparent links between education, learning and teaching: learning is often assumed (rightly or wrongly) to be a causal or other consequence of teaching, and the terms 'education' and 'teaching' are sometimes used interchangeably. [...] there is a fairly common association between education and schooling". In this context, Michael Uljens (1997, p. 63) draws attention to the importance of didactics: "[...] The aim of school didactics is to provide a conceptual language by which we may talk about educational reality in the institutionalized school. [...] Traditionally many educators have worked with problems explicitly related to teaching and learning in schools". 
2002 , p. 221) of the teacher and is oriented towards student transfer rather than constructing meanings - "knowledge in search of footsteps" (ibidem).

The second concept stems from a clear and direct opposition to a traditional, dominating model of education in Poland - also nowadays (Klus-Stańska, 2002, p. 268). The immediate temptation of strengthening student's independence and self-sufficiency in learning with simultaneous restriction of teacher's role leads to a simplified assumption that student's autonomous learning is synonymous to education. Student and his learning activities are leading to his educational emancipation.

The above explanations could be presented in the juxtaposition that learning equals education. This assumption indicates that students are able to learn on their own and take the lead in different stages of the lesson. Teachers on the other hand just facilitate and manage students' effective learning and are not active participants of education process (Uljens, 1997; Biesta, 2006; 2017).

The third and last educational concept of pedagogical culture assumes that both participants of school lessons, a student and a teacher, are still equally vital and their shifted, unique actions are noticeable at all stages of education, e.g. introducing new information, setting goals, grading, testing knowledge etc. A two dimensional process which emerges here includes "visible learning" - a student and his learning activities leading to student's educational emancipation, "visible teaching" a teacher and his teaching practice which triggers student's proactivity and "visible education" a correlation of "visible learning" and "visible teaching" interactions.

The above explanations are presented in the juxtaposition that "visible teaching" combined with "visible learning" equals "visible education". Two elements of this arrangement deserve particular attention: first, education as combinations of two types of activities - the teaching that comes from the teacher and the learning that the student is to perform. Secondly, I preceded all terms with the adjective "visible". I derived this idea from John Hattie, who is known for publications on Visible Learning theory - all factors triggering school learning. In this article the term "visible learning" is narrowed to a shifted model of a student and his learning activities leading to student's educational emancipation - the ability to use acquired knowledge in real life situations.

"Visible teaching" is the article's author own understanding of a shifted model of a teacher and her teaching practice which triggers student's proactivity. The expression "visible education" will be used as a correlation of "visible learning" and "visible teaching" processes. This new model of education is "visible" both to a teacher and a learner. Teacher triggers the learning process because he sees his teaching from students' perspective: identifies with students, predicts their difficulties, invites them to cooperation etc. Student on the other hand responds to teacher's invitation by adopting more proactive, mature attitude which is connected with looking at his learning through teacher's lenses. 
With that in mind, the term "visible education" is understood as (1) a correlation of teacher's teaching visible to a student and student's learning visible to a teacher and as (2) mentioned above educational emancipation - acquiring, thanks to teacher's support, certain knowledge and skills that are needed in everyday life ${ }^{2}$, which student would not be able to possess in any other way (Uljens, 1997; p. 24-25; Uljens \& Ylimaki, 2017, p. 10-11).

\section{Visibility in educational processes}

To explain the importance of visibility in educational processes, I refer below to J. Hattie's Visible Learning concept, but at the same time I pay the attention to ambiguities regarding understanding of “visible education”. Before however, I will briefly present his research.

\section{Evidence based research and visibility}

J. Hattie's concept is the largest in history "culmination of more than 25 years of examining and synthesizing more than 1,600 meta-analyses comprising more than 95,000 studies involving 300 million students around the world" (The world's largest...). His research has been designed as a meta-meta-study that gathers, compares and examines the results of many previous studies in education (e.g. journal articles, books, research reports etc.). He has focused on education in English-speaking countries but most characteristics of the fundamentals may be applicable to all countries and school systems.

The research considers about 250 variables, e.g. class size, holidays, feedback, learning strategies etc. that have been classified into main didactics based domains: Student (background, beliefs, and physical influences), Teacher (teacher attributes, teacher-student interactions, teacher education), Curricula (various curricular programs), Student Learning Strategies (self-regulation, student perspectives, and learning strategies), Teaching Strategies: (learning intentions, success criteria, feedback, and teaching strategies), etc. The established domains suggest that Hattie looks at school education through the eyes of a teacher and provides educators with practical and valuable hints for their teaching practice which in turn trigger students' role.

In order to explain visibility of teaching and learning in everyday school practice J. Hattie (2008; 2015) systematises and organises factors, by using effect size filter. A measure developed by J. Hattie presents the impact of teaching and learning activities on the effect achieved by the learner. There are 4 ranges of effect size

2 English term "education" begins to take on here the meaning of an effect, product of teaching and learning. It corresponds with German word Bildung, which classically means "intrinsic formation" (Masschelein \& Ricken, 2003, p.141). 
which can be illustrated with examples of a single activity dependent on two vital participants of educational processes: a student and a teacher, from each range, e.g. Negative effect on a student's success: Retention (-0.16), Television (-0.18); Low effect: Richer subject matter knowledge (o.09), Diet (o.12); Medium effect: Homework (o.29), Personality (o.19); High effect: Teacher clarity (o.75), and Selfreported grades (1.44).

Through a great number of variables and the measure of effect size that accompanies them, J. Hattie wants teachers and students to look at their own actions and determine which of them bring positive effects. Thanks to this procedure teachers and students gain two types of visibility. The first one is quite scientific depicts participants' educational actions with the use of research and certain statistical measures (Hattie, 2008; see also Biesta, 2009). The other type of visibility is rather practical - J. Hattie's (2003; 2015; Hattie et al. 2016) research is intended to change school practice: teachers draw conclusions from existing school reality and by shifting their actions transform it.

\section{Visible learning}

According to J. Hattie (2015) students' "visible learning" strategies have enormously positive effect size which equals 1.41. In order to fully understand this high effect size in the context of school learning we should compare it to what J. Hattie called a "hinge point". A "hinge point" (o,40 effect size) is "the average point at which we can consider that something is working well enough for a student to gain one year's growth for a year of schooling" (Hattie et al., 2016, p. 21).

Therefore, if school learners focus on performing actions that are assigned to the zone of desired effects (o,40 and above) they will make progress bigger than what is expected from attending the school for a year! Moreover, as N. Frey, J. Hattie and D. Fisher (2018) explain, students who can be referred to as "visible learners" possess special qualities and perform behaviours that allow them to be their own teachers, articulate what they are learning and why, talk about how they are learning, articulate their next learning steps, use self-regulation strategies, be resilient, aspire to challenge, set mastery goals, see errors as opportunities and are comfortable saying that they do not know/ or need help, positively supports peers' learning, know what to do when they do not know what to do, actively seek feedback, have metacognitive skills and can talk about these skills.

\section{Visible teaching}

The research conducted by J. Hattie (2003) has shown that second most important influence on student's achievement (apart from student himself - 50\% of the variance of achievement) is a teacher and the way he thinks about teaching (30\% of the variance). Referring to the N. Frey, J. Hattie and D. Fisher (2018) it can 
be said that "visible teacher" plays an indispensable role of a trigger for "visible learner's" appearance in education process. Therefore, it is worth explaining who "visible teacher" is.

To clarify the above issue, J. Hattie and K. Zierer (2017) presented a list of teacher's 10 mindframes which help traditional educator to put himself in the shoes of students and acquire the mindset of a "visible teacher". The first group of three mindframes is connected with the impact a teacher has on his/her students: "I am an evaluator of my impact on student learning", "I see assessment as informing my impact and next steps", "I collaborate with my peers and my students about my conceptions of progress and my impact". The next pair of teacher's mindframes talks about bringing the change and challenge into the school education: "I am a change agent and believe all students can improve", "I strive for challenge and not doing your best". The last group of five mindframes refers to learning focus: "I give and help students understand feedback and I interpret and act on feedback", "I engage in dialogue much as monologue", "Success criteria is critical, I build relationships and trust so that learning can occur in a place where it is safe to make mistakes and learn from others", "I talk about learning, not about teaching".

\section{Visible education}

There are many reasons why "visible education" is crucial in achieving school success. First of all it allows students to gain even one year progress, which consequently results in better exam results (Hattie et al., 2016, p. 21). Moreover, they get more involved in the lesson, and gain key competences. Finally, schoolwork is less stressful both to teachers and students. But the key point is that "visible teaching" cannot occur without "visible learning" and vice versa. As J. Hattie (2018) emphasizes student's and teacher's actions are dependent on each other and are equally important elements of "visible educational" process: teachers and students working together as evaluators of their impact effect size $=0,9$; errors and trust as opportunities to learn $=0,72$; teachers and students having high expectations $=$ 0,9 etc. Those processes occur as a didactic method where a teacher and students are not afraid of taking risks and strive to challenge the educational status quo. It is possible when through professional qualifications and teaching competences the educator becomes a perceptive observer and a persistent researcher of the processes taking place at his lesson and as a consequence he starts asking himself and students questions, e.g. "What do I do as a teacher/student? What do I achieve at school? What can or should I change in my everyday school work?" (Hattie \& Zierer, 2017, p. Xv).

It is also crucial that the teachers incorporate personal, social, study techniques, citizenship or entrepreneurship key competences into the aims of the lessons (Navracsics [Ed.], 2019). At the same time students may fully meet their developmental needs in the school environment: possibility of active participation 
in creating school environment, experiencing and solving conflicts in cooperation with others, fair assessment, supplying clear feedback, the ability to perform various roles, initiating and participating in social integration, implementing creative changes and delegating tasks (Jabłoński \& Wojciechowska, 2013, pp. 51-52). Effective "visible education" entails a constant flow of actions and reactions between the teacher and students.

The above considerations of three diverse educational concepts do not exhaust the subject, but offer vital viewpoints and additional suggestions that may shed some light on what "visible education" is. It appears, thus, that this is not a specific idea, but rather a certain direction in thinking, which enables a teacher to understand his own teaching and learner his own learning as components of pedagogical activity. This pedagogical activity always has a dual character (Gara, 2018). The "visible education" idea will serve as a prism for presentation and analysis of three bottom-up initiatives which aim at reforming Polish public school.

\section{Educational initiatives in Poland from the visibility perspective}

Polish public school teachers who observe ineffectiveness of traditional Prussian schooling model take actions that aim to modify it. Especially three clear initiatives are worth considering: Wake up School, Non Violent Communication and Dalton Plan. I will analyse each of them from the "visible education" perspective.

\section{Dalton (Laboratory) Plan in Poland}

The Dalton Plan stemmed mainly from education philosophy of John Dewey. Its creator Helen Parkhurst, as a seventeen year old teacher of 40 students class, wanted to organise an effective personalized education for her students whose age ranged from 6 to 16 (Sowińska \& Sowiński, 2019). The Dalton Plan first appeared in Poland during the interwar period (1918-1939) and was successfully implemented in schools in Chełm, Krzemieniec, Warsaw, Krakow Rydzyń (Śliwerski, 2011, p. 13). Its current form implemented in Poland benefits from Czech and Dutch experiences (Moraczewska, 2013).

Responsibility, independence and cooperation, which constitute and strengthen human functioning in society are three basic pillars of the Dalton Plan. The main objective of the Dalton school is to prepare young people for life in a society. According to Anna Sowińska (2017, p. 32) it requires a shifted attitude: from thinking of what students do not know and cannot do to thinking of what they already know and what skills they already possess.

A teacher is a crucial creator of three mentioned educational pillars and his traditional role is changed - he is among the children, does not hide behind the desk close to the blackboard (Röhner, 2012, p. 5). Therefore, he plans the educational activity beforehand, uses specially designed teaching material and coaches students 
through the task. Despite this the role of teaching activity is unnoticed and seems to be irrelevant. A teacher can be compared at this point to a manager who organises the process of students' learning, who smoothly delegates part of his tasks to the learners, coaches them and in return, the students' job, is to manage their own time and activities. Teaching activity is disregarded and a teacher does not impersonate himself as a student therefore "visible teaching", within the meaning of J. Hattie's theory, is not possible.

It is believed that when students are equipped with a well-arranged classroom and teaching aids, are familiarised with the aim and meaning of the task and know classroom rules, they are ready and able to learn independently. In this way a learner gets included into the educational process and consciously decides about the course of his educational path (Reinhard, 2018). During a schooling process a student takes on the role of an active researcher and explorer (Konieczko, 2012, p. 16) and gets equipped with specific skills and key competences beneficial not only at the next levels of education but primarily in the modern world.

Although "there is no historical-theoretical literature available on the Dalton Plan as an educational concept" (van der Ploeg, 2014, p. 3) it successfully operates in some Polish public schools nowadays again (Dryjas, 2012). A teacher's approach to learning and his organizational skills lead to strengthening students' feeling of independence and responsibility. As H. Pankhurst (1928, p. 3) stated: "Formerly the student went to school to get what school had to offer him; now he goes to school to fulfil a specific need for self-development. A child does not want to learn anymore just what the teacher recommends". School teachers confirm that their activities are understood and consciously followed by students and that students' individual learning processes are clear and visible to a teacher (Reinhard, 2018, p. 81).

The overall picture emerging from the above considerations is that the Dalton education model fits in well into the model that learning equals education. The teacher performs here a role of a skilful "craftsman" by manufacturing wellconsidered teaching aids, materials and does not participate in subsequent stages of the lesson. Such actions are not in accord with visibility - looking at teaching from student's perspective. Learning occurs through well prepared materials and carefully arranged tasks. Students learn by themselves, which is incompatible with "visible learning" either. As I have noticed above "visible education" takes place with simultaneous, active participation of a teacher and a student. As there is no teacher's didactic involvement, the Dalton education seems to be understood only as liberation of one participant - a student, not as a visible process.

\section{Non Violent Communication in Polish school}

The Nonviolent Communication (NVC) concept which supports partnership and resolves conflicts among people has been developed by an American psychologist Marshall Rosenberg around 1970. Good relationships based on trust, mutual 
exchanges, empathy and creating friendly environment for students, teachers and parents are the basis of the educational process. NVC practitioners focus their attention on four components of effective everyday communication and cooperation: (1) observation: the facts not generalizations, (2) feelings: emotions or sensations, free of thought and story, (3) needs: universal human needs, and (4) request: request for a specific action, free of demand.

A Polish public school teacher who has successfully worked out proactive and innovative teaching methods grounded in NVC is a secondary school mathematics teacher - Anna Szulc (2019). NVC at school means something more than just exchanging information and curriculum between a teacher and a student. It develops a quality relationship which is present in every aspect and stage of the lesson. Therefore, NVC in school enables a student to develop a certain growth mindset. This teaching style integrates teacher's subject knowledge with expertise in such areas as psychology, tutoring etc. A teacher is a mentor who supports students' growth and guides them into the world of universal values (MarczyszynBerendt, 2018).

In order to meet all the above requirements a teacher needs to be an open minded, emphatic and reflective practitioner who constantly improves his methods of teaching. Those listed features correspond with Hattie's (2003) list of prototypic attributes of a great teacher. Teacher's main task - creating conditions for student learning is visible at A. Szulc's (2019) subject assessment rules: individual student's development, grades are not the aim, all tests can be retaken many times and the terms are adjusted to particular student's needs; a student decides which grade is final; mistakes are treated as natural stages in learning and students are not criticised for making them, homework is not compulsory etc.

NVC teacher is emphatic and willing to support students: encourages them to ask questions and collaborate, creates a stress-free assessment, respects and appreciates mistakes, treats misbehaviour as a sign of need to support students, does not use praises and punishments. In this way he builds his authority in the class and students are able to recognise and reflect on their learning. It all proves visibility of teaching.

A redefined role of a teacher triggers the new role of a student. When a teacher offers constructive feedback, a student is able to see his progress, when a teacher appreciates and analyses student's mistakes it leads to student's recognition and work on his weaknesses. A. Szulc's students become proactive participants of their education process: participate in creative tasks, cooperate with peers, use mnemonic techniques, participate in classroom discussions, are engaged in setting classroom rules, give a teacher feedback on her work, suggest their own solutions to problems, decide on their own grades etc. Procedures used by the author in everyday school situations activate students' self-confidence and responsibility for their decisions, education and growth. Consequently, cheating or demanding attitude among students, which is observed as a frequent public school problem, does not exist 
here (Sarbiewska, 2019b). Instead students present a markedly greater motivation, sense of responsibility and empowerment.

School is a place of ongoing diverse cognitive processes. NVC concept application involves active student-teacher communication at different stages of the lesson and at a large scope without omitting or excluding any of the participants. Each of them provide feedback and reflection of the undertaken actions that lead to highlighting the teacher and students' assets (Łazarczyk, 2018).

The above considerations indicate a link between dialogue, school and quality education where "visible learners" together with their "visible teacher" are equal to good cooperative schoolwork. Here successful school education depends on a teacher and students' separate, harmonious and synergetic activities of teaching and learning. A redefined teacher's professional and personal concept of an authentic person who accepts his own and others' mistakes, is empathetic, asks questions, appreciates feedback, triggers analogous students' mindset. Students are proactive, take responsibility for their own decisions, provide valuable feedback. "Visible teaching" corresponds here with "visible learning" therefore public school becomes a rich environment enabling education of creative, decisive and responsible young people who fulfil their development needs in school environment. Such a school facilitates education processes to become more visible.

\section{Wake Up School movement}

Polish Budząca-się-szkoła [Wake Up school] movement is an implementation of a German Schule-im-Aufbruch model of education. It is based on the brain-friendly learning approach (neurodidactics) and a unique belief that "nobody is teaching but Students are learning" (Żylińska, 2017). For this reason a traditional teacher's role is reduced here, a teacher does not participate in all stages of the lesson or education process, he does not explain how something can be done better and faster - students are supposed to discover it on their own using all available resources. A teacher performs here a redefined role of a tutor, coach and designer of school's educational space (Żylińska, 2016). He defines educational goals, encourages students to look for their own learning paths, provides student's learning assistance, supports solving their personal and social problems. The role of a personal development coach allows a teacher to arouse student's diverse interests and support students' potential development. As a creator of the learning environment a teacher creates structural and classroom conditions for student's self-organized individual learning process by enabling them to browse through high quality learning materials. With the use of neurodidactics a teacher understands the processes of learning occurring in student's brain and uses brain-friendly approach. Although teaching lacks here highly effective didactic actions within the meaning of J. Hattie's research, it is considered to create positive conditions for student's learning which shall be brain-friendly. 
According to the creators of Polish School Awakening movement, students' learning should be based on four pillars described by Jacques Delors (1996, p. 17) in UNESCO Commission on Education for the Twenty-first Century report: learn to know, learn to be, learn to live together, learn to do. According to a promoter of neurodidactics in Poland, Marzena Żylińska (2016), student's role is to actively explore the world - take responsibility for his learning and time management, learn through cross-curricular projects, learn from personalized interesting teaching materials and through problem-solving tasks. All those procedures are supposed to trigger student's joyful experience. Students equipped with learning and metacognitive competences develop their potential, strengths by focusing mainly on competences, rather than pure facts and subject knowledge.

Effective education occurs in a culture of learning which according to $\mathrm{M}$. Żylińska (DNA Budzącej się szkoły...) is based on 10 transitions that constitute principles of neurodidactic approach: from a culture of teaching to a culture of learning, from mistakes to appreciation, from school subjects to projects, from standardization to personalization, from subordination to autonomy, from punishment to conversation, from listening to acting, from hierarchy to partnership, from testing to solving problems.

The discussed concept creates an educational model where "visible learning" equals teaching. An educator understands neuronal processes of student's learning and does not impose anything on students. Teaching means here looking at student's learning through the prism of neurology. A teacher with his neurodidactic knowledge recognises this learning - and, paradoxically, "visible learning" is teacher's, not student's domain. Learning is understood as a natural and spontaneous activity that students undertake as soon as external obstacles, including teacher and his traditional Prussian activities disappear.

School Awakening initiative suggests that education does not have to occur in traditionally understood school or classroom conditions, or even in a school building. Education is associated here with developing child's natural potential and teacher's role is to protect students' inborn drive to knowledge and "not to disturb" them with acts of teaching. Just like in the "Hole in the wall" experiment (Mitra, 2012), students are expected to find a pathway to learning. "Visible education" does not appear here because it requires active cooperation, mutual interest and mutual support of a teacher and students at different stages of the lesson and assimilation of growth mindset.

\section{Synthesis}

Polish teachers who observe ineffectiveness of traditional Prussian education model dominating in public schools and who experiment with alternative concepts, discover interesting answers to their concerns and questions. 
The Dalton Plan and School Awakening education concepts seem to follow some kind of a shortcut - submitting a teacher and his activities to a dominating role of a student. Student's learning is here well understood, valued and in consequence student's actions become more developed and advanced. Student takes over the role of his own teacher with conscious use of mnemonics, time management etc. On the other hand, teacher and his unique actions are ignored. Teacher performs here a different, not assigned to his primary profession role of a coach, manager, coordinator etc. Teaching activity seems to be excluded from various stages of the lesson and widely understood school education. Unfortunately, even the most developed and advanced "visible learning" activities do not create "visible education" because it is not fuelled by "visible teaching".

The educational model incorporating Non-Violent Communication reinforces visible teacher's and learner's actions. The first participant of a schooling process -- a "visible teacher" is present in all stages of the lesson, looks at teaching from students' perspective: shares power, control and takes responsibility for education with students, is emphatic, appreciates mistakes as inevitable and crucial steps in learning. The other participant of this educational model - a "visible learner", looks at learning from teacher's perspective: takes responsibility for his decisions and results, is aware of educational goals and why achieving them is important, plans his further educational journey (knows where he is, where he needs to get and what he needs to do to get there). This model seems to be directed at "visible education" idea.

The analysis of initiatives presented above indicates that "visible teaching" and "visible learning" take place at school and school conditions determine teaching and learning. However, those processes do not occur automatically. In order to achieve success a teacher cannot help a student in learning but may only support him through his own teaching actions (Stępkowski, 2018, p. 92). The solutions introduced into the everyday school practice would benefit much more if they were related to the forgotten didactics and its intermediated position between a student, who is learning, and a curriculum taught by a teacher. It is worth to consider the model of school system where a teacher is teaching, a student is learning and both of them are involved in their own actions, each of them depends on the actions of the other participant.

Educators who try to improve Polish education seem to misunderstand teaching and learning and consequently go to extremes. The first extreme - present-day school education dominated by a teacher and his actions, students adjust to existing reality, sit straight, listen, take notes and do not disturb teachers (Klus-Stańska, 2012). Second extreme - modern school education dominated by students and learning, teacher's modified role is limited to coordinating, managing and coaching students, not interfering with their learning (Żylińska, 2017).

Unfortunately, the undertaken initiatives do not get right to the heart of the matter. When promoters of a particular educational initiative focus only on learning 
they lose sight of teaching activity, similarly when they focus only on teaching, they lose sight of learning. Therefore, we may draw the conclusion that the biggest problem in these bottom-up initiatives is not connected with combining two actions: teaching and learning, because those initiatives incorporate separately teacher's or learner's points of view instead of in conjunction with each other. The major problem though, exists in not seeing the activity of other actor in the educational process - the teacher of students' and students of teacher's. Only perceiving those actions leads to a successful educational process.

\section{Conclusions}

As Buckminister Fuller said "You never change things by fighting against the existing reality. To change something build a new model that makes the old model obsolete" (Ratcliffe \& Lebkowsky, 2005, p. 101). The three initiatives described here with their undeniable, valuable solutions aiming at education improvement fit well into the concept of pedagogical culture.

The visibility of educational processes based on J. Hatti's scientific research gain practical, everyday school relevance through application of size effect. In this context, we can say that school practice in Australia and New Zealand has been transformed on the basis of empirical research data (Sarbiewska, 2019a). Polish educational initiatives discussed in the article present a different form of visibility - based on a theory formed by its creators. Therefore transformations of Polish educational system cannot be treated as comparable to those in Australia and New Zealand, where the basis of visibility of educational processes is simply different. Comparison and assessment of those two approaches, one based on scientific research and the other based on a pedagogical theory, would provide a valuable voice in discussion about possible directions of changes in the Polish education system.

\section{References}

Biesta, G.J.J. (2006). Beyond learning: Democratic education for a human future. New York: Paradigm Publisher.

Biesta, G.J.J. (2009). Good education in an age of measurement: on the need to reconnect with the question of purpose in education. Educational Assessment Evaluation and Accountability, 21(2), 33-46.

Biesta, G.J.J. (2017). Lead Learner or Head Teacher? Exploring Connections Between Curriculum, Leadership and Evaluation in an 'Age of measurement'. In M. Uljens \& R.M. Ylimaki (Eds.), Bridging educational leadership, Curriculum theory and didactic. Cham: Springer.

Carr, D. (2003). Making sense of education. An introduction to the philosophy and theory of education and teaching. London-New York: Routledge Falmer. 
Delors, J. (1996). Learning: the treasure within; report to UNESCO of the International Commission on Education for the Twenty-first Century. Retrieved from: https:// unesdoc.unesco.org/ark:/48223/pfoooo109590 (25.03.2020).

DNA Budzacej się szkoły. Retrieved on: http://www.budzacasieszkola.pl/wspieramy-w-rozwoju/programy-rozwojowe/ (25.03.2020).

Dryjas, K. (2012). Koncepcja edukacji daltońskiej droga do rozwoju samodzielności i autonomii dziecka. Retrieved from: https://blizejprzedszkola.pl/upload/files/ Koncepcja_edukacji.pdf (25.03.2020).

Frey, N., Hattie, J., \& Fisher, D. (2018). Developing Assessment-Capable Visible Learners, Grades K-12: Maximizing Skill, Will, and Thrill. SAGE Publications.

Gara, J. (2018). Casus dwupodmiotowości myślenia i działania pedagogicznego. In J. Gołkowska, K. Sipowicz, I. Patejuk-Mazurek (Eds.), Tradycja i współczesność pedagogiki specjalnej $w$ tworzeniu społeczeństwa dla wszystkich (pp. 423-441). Warszawa: Wydawnictwo Akademii Pedagogiki Specjalnej.

Hattie, J. (2003). Distinguishing Expert Teachers from Novice and Experienced Teachers. Retrieved from: https://research.acer.edu.au/cgi/viewcontent.cgi?arti $\mathrm{cle}=1003 \&$ context=research_conference_2003 (25.03.2020).

Hattie, J. (2008). Visible Learning. New York: Routledge.

Hattie, J. (2015). The applicability of Visible Learning to Higher Education. Scholarship of Teaching and Learning in Psychology,1(1), 79-91.

Hattie, J. (2018). 10 Mindframes For Visible Learning Webinar. Retrieved from: https://www.youtube.com/watch? $=\mathrm{tANBHAy} 5$ DDU\&list=PL6-HcJKsXgYHt6529jZP8Y_S28nFc9L6K\&index=3 (25.03.2020).

Hattie, J., \& Zierer, K. (2017). 10 Mindframes for Visible Learning: Teaching for Success. London-New York: Routledge.

Hattie, J., Fisher, D., Frey, N., Gojak, L.M., Delano Moore, S., \& Mellman, W. (2016). Visible Learning for Mathematics, Grades K-12: What Works Best to Optimize Student Learning. Corwin Press.

Jabłoński, S., \& Wojciechowska, J. (2013). Wizja Szkoły XXI Wieku: Kluczowe kompetencje nauczyciela a nowa funkcja edukacji. Studia Edukacyjne, 27(2), 43-63.

Klus-Stańska, D. (2002). Konstruowanie wiedzy w szkole. Olsztyn: Wydawnictwo UWM.

Klus-Stańska, D. (2012). Wiedza, która zniewala. Transmisyjne tradycje w szkolnej edukacji. Forum Oświatowe, 1(46), 21-40.

Konieczko, E. (2012). W drodze do edukacji daltońskiej. Retrieved from: https:// dalton.org.pl/wp-content/uploads/2017/11/miedzynarodowa-konferencja-dalton-2012.pdf (25.03.2020).

Łazarczyk, M. (2018). NVC w edukacji. Retrieved from: http://fundacja-trampolina. org.pl/nvc-w-edukacji/ (25.03.2020).

Marczyszyn-Berendt, J. (2018). Wdrożenie NVC w szkole. Retrieved from: https:// nvclab.pl/wdrozenie-nvc-w-szkole/ (25.03.2020). 
Masschelein, J., \& Ricken, N. (2003). Do We (Still) Need the Concept of Bildung? Educational Philosophy and Theory, 35(3), 139-154.

Mitra, S. (2012). The Hole in the Wall Project and the Power of Self-Organized Learning. Retrieved from: https://www.edutopia.org/blog/self-organized-learning-sugata-mitra (25.03.2020).

Moraczewska, B. (2013). Plan daltoński jako narzędzie dla współczesnej edukacji. Konieczność czy ekstrawagancja?, Studia Gdańskie. Wizje i rzeczywistość, 9(1), 351-364.

Navracsics, T. (2019) (Ed.). Key competences for lifelong learning. Retrieved from: https://op.europa.eu/en/publication-detail/-/publication/297a33c8-a1f3-11e99do1-01aa75ed71a1/language-en (25.03.2020).

Parkhurst, H. (1928). Wykształcenie według planu daltońskiego. Lwów: Książnica Atlas.

Ratclife, M., \& Lebowsky, J.(2005). Extreme Democracy. Morrisville: Lulu.com

Reinhard, K. (2018). Szkoła - uczeń - życie. Współczesne wyzwania, niepokoje i nadzieje. Pedagogika Przedszkolna $i$ Wczesnoszkolna, 6(2), 73-82.

Röhner, R. (2012). Czy Dalton jest aktualny w obecnych czasach? Retrieved from: https://dalton.org.pl/wp-content/uploads/2017/11/miedzynarodowa-konferencja-dalton-2012.pdf (25.03.2020).

Sarbiewska, A. (2019a). Visible Learning and educational policies in New Zealand and Australia. Kultura $i$ Wychowanie, 2(16), 116-132.

Sarbiewska, A. (2019b). Reforming the educational system in Poland: The practice-based perspective. Forum Pedagogiczne, 2(2), 301-304.

Sowińska, A., \& Sowiński, R. (2017). Od nauczania do uczenia się: Nasz Plan Daltoński. Łódź: SOR-MAN.

Sowińska, A., \& Sowiński, R. (2019). Dlaczego Plan Daltoński? In M. Żylińska (Ed.), Nurty edukacji alternatywnej $w$ świetle wiedzy o procesach uczenia się. Toruń: Edukatorium.

Stępkowski, D. (2018). Nauczanie wychowujące - dialogiczna rama dla praktyki edukacyjnej i myślenia ogólnopedagogicznego. Studia Z Teorii Wychowania, 9(2), 79-100.

Szulc, A. (2019). Nowa Szkoła. Szczecin: Wydawnictwo Natuli.

Śliwerski, B. (2011). Recepcja planu daltońskiego Helen Parkhurst w Polsce. In R. Rohner \& H. Wenke (Eds.), Pedagogika planu daltońskiego. Łódź: SOR-MAN.

The world's largest evidence base on what works best in schools to accelerate student learning. Retrieved from: https://www.visiblelearning.com/content/visible-learning-research (25.03.2020).

Uljens, M. (1997). School Didactics and Learning. London: Psychology Press.

Uljens, M., \& Ylimaki, R.M. (Eds.), Bridging Educational Leadership, Curriculum Theory and Didaktik. Cham: Springer.

van der Ploeg, P. (2014). Dalton Plan. Retrieved from: https://www.researchgate. net/publication/274570432_Dalton_Plan (25.03.2020). 
Żylińska, M. (2016). Kompas Budzacej się szkoty. Retrieved from: http://www. budzacasieszkola.pl/wp-content/uploads/2016/o3/Kompas-Budz\%C4\%85cejsi\%C4\%99-szko\%C5\%82y-1.pdf (25.03.2020).

Żylińska, M. (2017). Powinniśmy odejść od kultury nauczania i wprowadzić kulturę uczenia się. Retrieved from: https://dziecisawazne.pl/marzena-zylinska-1/ (25.03.2020).

\section{EDUKACJA I WIDOCZNOŚĆ ZACHODZĄCYCH W NIEJ PROCESÓW: INICJATYWY TRANSFORMACJI SZKÓŁ W POLSCE}

Streszczenie: Na podstawie teoretycznego modelu kultury pedagogicznej przeanalizowano $\mathrm{w}$ artykule trzy współczesne inicjatywy edukacyjne w polskich szkołach publicznych. Rozważania obejmują działania związane z nauczaniem, uczeniem się i związkiem między nimi wyrażonym pojęciem edukacji. Tekst składa się z czterech części. W pierwszej zaprezentowano kulturę pedagogiczną, wyszczególniając trzy teoretyczne modele kształcenia. Druga część zawiera zestawienie pojęcia „widoczność” wywodzącego się z badań opartych na dowodach z procesami edukacyjnymi. Trzecia część przybliża w kontekście idei widocznej edukacji podstawy współczesnych inicjatyw pedagogicznych: Plan daltoński, Komunikacja bez przemocy oraz Budząca się szkoła. Ostatnia część artykułu zawiera ocenę omówionych projektów udoskonalenia edukacji szkolnej.

Słowa kluczowe: widoczność; uczenie się; nauczanie; kształcenie; Komunikacja bez przemocy; Budząca się szkoła; Plan daltoński. 